\title{
Neuroprotective Role of Vascular Endothelial Growth Factor: Signalling Mechanisms, Biological Function, and Therapeutic Potential
}

\author{
Ian Zachary \\ Centre for Cardiovascular Biology and Medicine, BHF Laboratories, Department of Medicine, \\ The Rayne Institute, University College London, London, UK
}

\section{Key Words}

Vascular endothelial growth factor · Angiogenesis •

Neuron · Endothelium · Neuropilin

\begin{abstract}
Vascular endothelial growth factor (VEGF or VEGF-A) and its receptors play essential roles in the formation of blood vessels during embryogenesis and in disease. Most biological effects of VEGF are mediated via two receptor tyrosine kinases, VEGFR1 and VEGFR2, but specific VEGF isoforms also bind neuropilins (NP) 1 and 2, non-tyrosine kinase receptors originally identified as receptors for semaphorins, polypeptides with essential roles in neuronal patterning. There is abundant evidence that VEGF-A has neurotrophic and neuroprotective effects on neuronal and glial cells in culture and in vivo, and can stimulate the proliferation and survival of neural stem cells. VEGFR2 and NP1 are the major VEGF receptors expressed on neuronal cells and, while the mechanisms mediating neuroprotective effects of VEGF are not fully understood, VEGF stimulates several signalling events in neuronal cell types, including activation of phospholipase C- $\gamma$, Akt and ERK. Findings in diverse models of nerve damage and disease suggest that VEGF has therapeutic potential as a neuroprotective factor. VEGF is a key mediator of the angiogenic response to
\end{abstract}

cerebral and peripheral ischaemia, and promotes nerve repair following traumatic spinal injury. Recent work has revealed a role for reduced VEGF expression in the pathogenesis of amyotrophic lateral sclerosis, a rare neurodegenerative disease caused by selective loss of motor neurons. In many instances, the neuroprotective effects of VEGF appear to result from a combination of the indirect consequences of increased angiogenesis, and the direct stimulation of neuronal function. However, more work is required to determine the specific functional role of direct neuronal effects of VEGF.

Copyright (C) 2005 S. Karger AG, Basel

\section{Introduction}

Since its initial discovery in 1983 [1] and subsequent cloning of the gene in 1989 [2, 3], vascular endothelial growth factor (VEGF-A, VEGF or vascular permeability factor) has been established to be an essential regulator of angiogenesis in both vertebrate development and in a variety of common chronic human diseases [4]. Alternative splicing of the human VEGF-A gene gives rise to at least six different transcripts, encoding isoforms (excluding signal peptide) of 121 (mouse equivalent, VEGF$\mathrm{A}_{120}$ ), 145, 165 (mouse VEGF-A $\mathrm{A}_{164}$ ), 183, 189 and 206 amino acid residues [5]. All transcripts contain exons 1-

\section{KARGER}

Fax +4161306 1234 E-Mail karger@karger.ch www.karger.com
(C) 2005 S. Karger AG, Basel

1424-862X/05/0145-0207\$22.00/0

Accessible online at: www.karger.com/nsg
Ian Zachary

Centre for Cardiovascular Biology and Medicine, BHF Laboratories

Department of Medicine, The Rayne Institute, University College London

5 University Street, London WC1E 6JJ (UK)

Tel. +44 207679 6620, Fax +44 2076796212 , E-Mail I.Zachary@ucl.ac.uk 
Fig. 1. VEGF ligands and their receptors. VEGFR1 (Flt-1) binds VEGF-A 165 , VEGF$\mathrm{A}_{145}$, VEGF-A 121, VEGF-B $_{186}$, VEGF-B $_{167}$, PLGF-1 and PLGF-2 (human isoforms). The extracellular domain of VEGFR1 is also independently expressed as a soluble protein (sFlt-1 or sVEGFR1), with predicted ligand specificity identical to that of the complete receptor. VEGFR2 (KDR) is a receptor for VEGF-A 165 , VEGF-A 145 , VEGF$A_{121}$, the processed forms of VEGF-C and VEGF-D (VEGF-C ${ }^{\Delta \mathrm{N} \Delta \mathrm{C}}$, VEGF-D ${ }^{\Delta \mathrm{N} \Delta \mathrm{C}}$ ) and the viral VEGF-Es encoded by strains D1701, NZ2 and NZ7 of the parapoxvirus Orf genome. Unprocessed VEGFs C and D bind VEGFR3 (Flt-4) with higher affinity. NP1, a non-tyrosine kinase receptor for semaphorin 3A (Sema 3A), is also a coreceptor for VEGF-A 165 , PLGF-2, VEGF$\mathrm{B}_{167}$ and $\mathrm{VEGF}-\mathrm{E}_{(\mathrm{NZ2})}$. NP2 binds only VEGF-A 165 and VEGF-A 145 . Only ligand isoforms that have experimentally been shown to bind particular receptors are shown. Details of receptor structures can be found in the box below the figure and in references 9 and 10 .

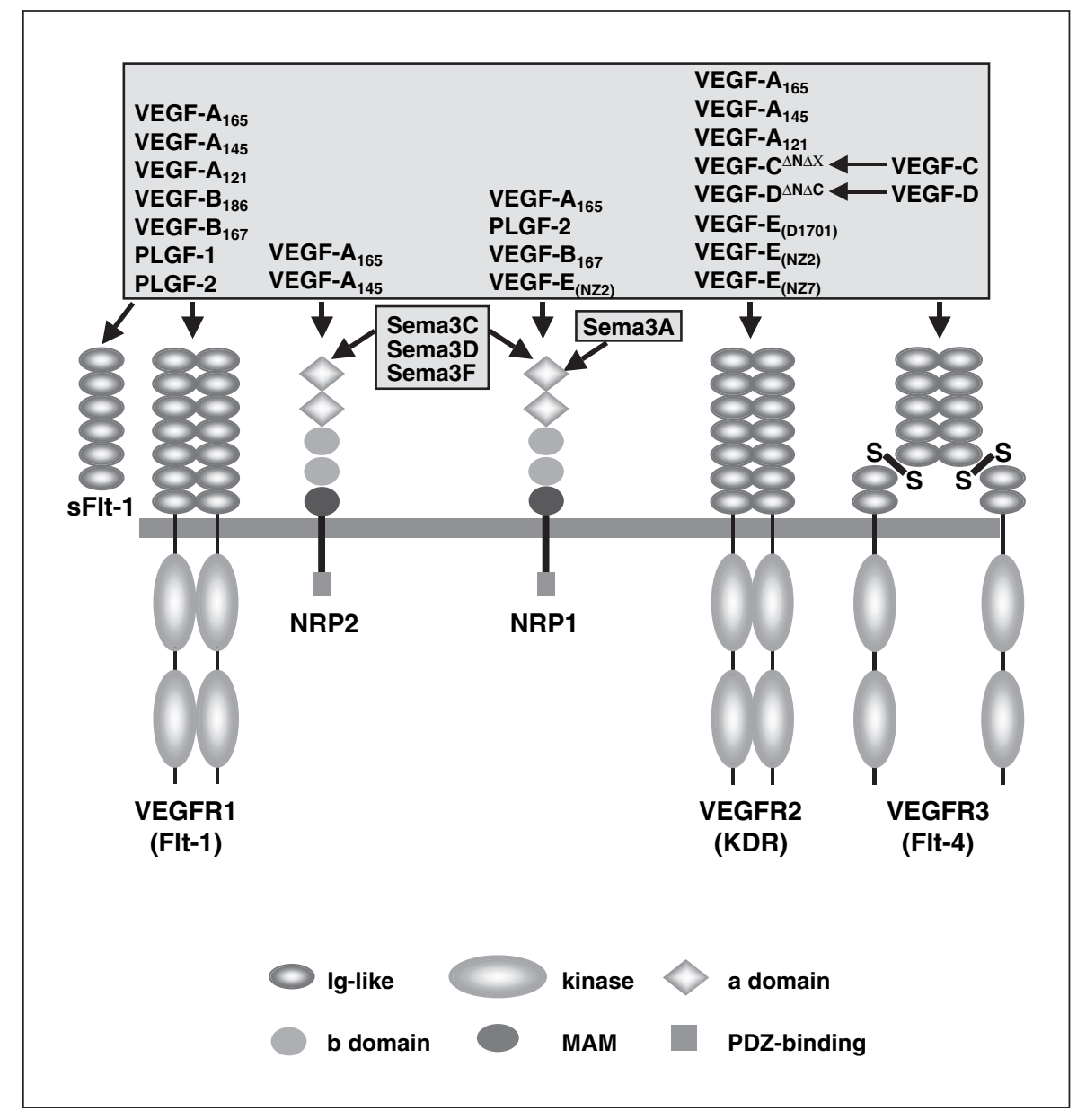

5, encoding the signal sequence and core VEGFR-binding or VEGF/PDGF homology domain, and exon 8, with diversity generated through the alternative splicing of exons 6 and 7. Exon 6 encodes a heparin-binding domain, while exons 7 and 8 encode a domain that mediates binding to neuropilin-1 (NP1) and heparin. Human VEGF$\mathrm{A}_{165}$, the most abundant and biologically active form, and VEGF-A $\mathrm{A}_{121}$ are secreted as covalently linked homodimeric proteins, whereas the larger isoforms, VEGF-A 189 and VEGF-A 206 , though thought to be secreted, are not readily diffusible and may remain sequestered in the extracellular matrix. VEGF-A is also the prototypical member of a family of related growth factors, which includes placental growth factor (PLGF), VEGFs B, C, and D, and the viral VEGF-Es encoded by strains D1701, NZ2 and NZ7 of the parapoxvirus Orf [6-8]. All VEGF family members are able to regulate angiogenesis, and in addition, VEGFs $\mathrm{C}$ and $\mathrm{D}$ are implicated as biologically important mediators of lymphangiogenesis; however, in contrast to VEGF-
A, the precise biological roles of other VEGFs are not yet fully understood.

The biological functions of VEGF-A are mediated via the protein tyrosine kinase receptors, VEGFR2 (KDR/ Flk-1) and VEGFR1 (Flt-1) [4, 9, 10]. Additionally, certain VEGF isoforms bind to neuropilins (NPs), non-tyrosine kinase transmembrane receptors (fig. 1). NP1 is a non-tyrosine kinase receptor for VEGF-A 165 , the heparinbinding PlGF-2 isoform, VEGF-B, and VEGF-E [11-14]. NP1 was first identified as a receptor for semaphorin $3 \mathrm{~A}$ (Sema 3A), a member of a family of polypeptides involved in axonal guidance and patterning $[15,16]$, and is expressed in endothelial cells, several tumour cell types and in certain types of sensory neuron including dorsal root ganglion (DRG), olfactory and optic nerves, as well as some sympathetic neurons $[11,17]$. VEGF-A $A_{165}$ also binds NP2 and VEGF-A ${ }_{145}$ binds specifically to NP2 [14], which has a similar domain structure to NP1 with $44 \%$ amino acid identity, and exhibits a distinct expression 
pattern in the developing nervous system $[16,18]$. Sema $3 \mathrm{~A}$ binds and induces neuronal growth cone collapse specifically through NP1, while Sema 3C, 3D and 3F recognise both NPs, though with differing affinities [18-21]. NPs also play essential roles in angiogenesis. Overexpression of NP1 in mice results in increased capillary formation, vasodilatation and malformation of the heart [22], whereas mice deficient in NP1 exhibit defects in embryonic axonal patterning and an array of vascular abnormalities including defective development of large vessels and impaired neural and yolk sac vascularisation [23]. Inactivation of both NP1 and NP2 causes a more severe failure of embryonic vascularisation resulting in death at E8.5 [24]. Though NP1-deficient mice are not phenocopies of the VEGF and VEGFR knock-out mice (see below), mice null for both NP1 and NP2 resemble knock-outs of either VEGF or VEGFR2 more closely. However, despite the strong evidence that NP1 is both essential for angiogenesis and is a major receptor for VEGF-A $\mathrm{A}_{165}$, its roles in VEGF biological functions have not been fully elucidated.

\section{Expression of VEGF and VEGFRs in the Nervous} System

During mouse embryogenesis, VEGF-A can be detected from embryonic day 7 (E7) in the extra-embryonic and embryonic endoderm, and by E8.5 is present at high levels in the trophoblast surrounding the embryo, and in the embryonic myocardium, gut endoderm, embryonic mesenchyme and amniotic ectoderm. Later in development, VEGF-A mRNA expression occurs in the mesenchyme and neuroectoderm of the head, and subsequently in the neuroepithelium and ventricular and choroid plexus epithelium of the developing central nervous system (CNS) [25-27]. VEGFR2 is highly expressed in vascular sprouts as they invade the neuroectoderm from day E11.5, and VEGFR2 expression remains high for the remainder of embryonic development and up to post-natal day 4 when vessel sprouting and endothelial proliferation are still very active [26]. VEGFR 1 is also found in the vascular networks adjacent to the neural tube $[25,27]$. In the developing rat brain, VEGF-A expression is confined to cortical neurons during early development, but undergoes a switch to maturing glial cells in close proximity to vessels, while expression in neurons falls to basal levels. However, exposure to hypoxia results in persistent neuronal expression and enhanced glial expression [28]. In the adult, expression of VEGF and VEGFR markedly declines in most tissues, and becomes restricted to a few regions of the brain, including the choroid plexus, area postrema and cerebellar granule cells [26, 29, 30], and in densely vascularised regions of the CNS such as the pars distalis cells of the pituitary and in retinal glial cells following an hypoxic insult $[31,32]$. VEGF expression is induced by hypoxia in astroglial cells [33,34], and is up-regulated in astrocytes at the site of spinal cord injury in the rat [35] and following CNS injury [36]. VEGF is also induced in peripheral nerves and dorsal root ganglia in a streptozotocin-induced model of type 1 diabetes [37]. Administration of VEGF to the cortex caused the up-regulation of VEGFR1 in brain astrocytes but not endothelial cells [38].

\section{Neurotrophic Effects of VEGF in Cultured Cells}

Expression of VEGF by peripheral and brain neuronal and glial cells in the CNS and peripheral nervous system is thought to be important for providing the essential cues directing vascularisation of the developing brain and nervous system, but it is increasingly recognised that VEGF has direct effects on neurons and glial cells (summarised in table 1). VEGF stimulates several neurogenic, protective and neurotrophic activities, including proliferation of astrocytes [39], Schwann cells [40, 41], microglia [42] and cortical neurons [43, 44]; protection of hippocampal, cortical, dopaminergic and peripheral sensory neurons as well as several neuronal cell lines against cell death induced by hypoxia, serum withdrawal or excitotoxic stimuli [39, 40, 45-47]; and axonal outgrowth, survival and inhibition of growth cone collapse in sensory DRG and retinal ganglion neurons, and sympathetic neurons of the superior cervical ganglion (SCG) [40, 48-50]. Intracerebroventricular administration of VEGF also stimulates the proliferation of neuronal cells in the subventricular and subgranular zones of the hippocampal dentate gyrus [44].

VEGF-A acting via VEGFR2 also has growth-promoting, survival and chemotactic effects on progenitor cells derived from regions of the brain that display spontaneous neurogenesis, such as the hippocampus, olfactory bulb and subventricular zone. VEGFR2 is expressed in mouse retinal progenitor cells [51], while VEGF-A, VEGFR2, NP1 and NP2 are expressed in neural stem cells (NSC), and VEGF-A increased survival of these cells under anoxic conditions [52]. VEGFR1 is also up-regulated in astrocytes after CNS injury [36]. VEGF-A also stimulated the expansion of VEGFR2-expressing rat NSC in culture, an effect that was blocked by inhibiting VEGFR2 kinase activity [53], and promoted the chemotaxis of neural progenitor cells from the subventricular zone, an effect dependent upon an increase in VEGFR2 
Table 1. Biological effects of VEGF on neuronal and glial cells in culture

\begin{tabular}{lll}
\hline Cell type & Biological effect & References \\
\hline CNS neurons & & $39,40,54,56,57$ \\
Cortical neuron & Proliferation, survival & 42,55 \\
Hippocampal neuron & Survival & 36 \\
Dopaminergic neuron & Survival & 53 \\
Cerebellar granule neuron & Survival & $37,44,45$ \\
\hline Peripheral neurons & & 37,44 \\
DRG & Axonal outgrowth, anti-chemorepulsion, \\
SCG & survival & 46 \\
RG & Axonal outgrowth, survival & 36,92 \\
\hline Glial cells & Axonal outgrowth & 37,38 \\
Astrocytes & & 39 \\
Schwann cells & Proliferation & \\
Microglial cells & Proliferation, migration & 41,52 \\
\hline Cell lines & Proliferation, migration & 43 \\
HN33 (hippocampal neuron $\times$ neuroblastoma) & Survival & 61 \\
SH-SY5Y (neuroblastoma) & Survival & \\
NSC34 (spinal cord $\times$ neuroblastoma) & Survival & 49,50 \\
\hline Neural progenitors & & 51 \\
Neural stem cells & Proliferation, migration, survival & \\
Dev (medulloblastoma) & Proliferation, migration, survival & \\
\hline
\end{tabular}

expression mediated by FGF-2 [54]. VEGF-A enhanced migration, proliferation and survival in the neuroectodermal progenitor cell line, Dev [55].

\section{VEGF Signalling in Neurons}

\section{Survival Signalling}

A major effect of VEGF in many neuronal cell types is protection against cell death induced by serum withdrawal, or exposure to hypoxia or excitotoxic stimuli. In several of these studies, the survival effects of VEGF are mediated by the anti-apoptotic pathway involving phosphatidylinositol 3'-kinase (PI3K)-dependent activation of the serine/threonine kinase, Akt or PKB. In HN33 cells, a line generated by fusion of mouse hippocampal neurons and neuroblastoma cells, VEGF promoted a survival effect mediated through VEGFR2 receptors, PI3K/ Akt, increased phosphorylation of IкB- $\alpha$ and nuclear translocation of the transcription factor NF- $\mathrm{B}[45,56]$. VEGF also promoted survival of the neuroblastoma cell line SH-SY5Y, via PI3K-dependent (wortmannin-inhibitable) tyrosine phosphorylation of the voltage-gated po- tassium channel, Kv1.2 [47]. VEGFR2 signalling via the PI3K/Akt and the MEK/ERK pathways also protected hippocampal neurons from glutamate-induced death [46], and the protective effect of VEGF in cerebellar granular neurons was dependent on the PI3K/Akt pathway but independent of ERK activation [57]. However, there is also evidence that the survival effects of VEGF in primary neuronal cultures may involve other mechanisms and, in some cases, be independent of the PI3K/ Akt pathway. VEGF rescued embryonic cortical neurons from hypoxic cell death via suppression of caspase-3 activity [58], while VEGF protected hippocampal neurons against death induced either by hypoxia or methyl- $D$-aspartate via a pathway independent of both PI3K and inhibition of caspase activation [59]. VEGF and hypoxia induced activation of extracellular signal-regulated protein kinase (ERK) and increased phosphorylation of p90RSK and STAT (signal transducers and activators of transcription) $3 \mathrm{a}$ in embryonic cortical neurons, but both these stimuli notably failed to increase Akt activity [60]. 


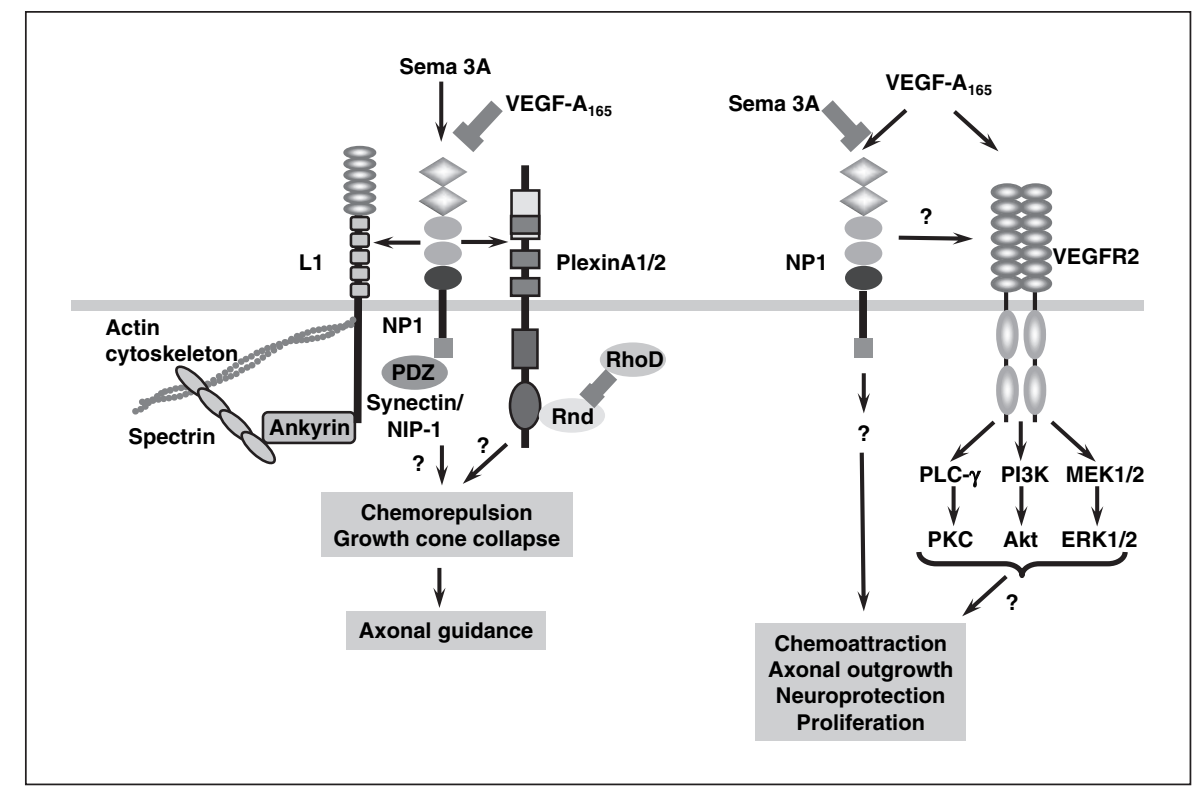

Fig. 2. Neuronal receptors for VEGF and downstream signalling mechanisms. The major receptors for VEGF detected in neuronal cells are NP1 and VEGFR2/KDR. VEGF-A 165 also competes with Sema 3A for binding to NP1. Left: Associations between NP1 and the transmembrane proteins, plexin $\mathrm{A} 1 / 2$ and $\mathrm{L} 1$, are required for Sema 3A-induced growth cone collapse. In turn, L1 binds directly to both actin and ankyrin, which associates with spectrin and the associated actin cytoskeleton. Recruitment of the small Rho-like GTPase, Rnd, by the plexin A1 intracellular domain is sufficient to induce growth cone collapse and this is antagonised by Rho D. NP1 also associates with the PDZ domain protein, synectin/NIP1/GPIC. VEGF competition with Sema 3A may regulate associations between NP1 and either plexin A1/2 and/or L1, but this re-

\section{Neuroproliferative Signalling}

The neuroproliferative effects of VEGF in embryonic cortical neurons are mediated via multiple signalling pathways, including MEK/ERK, PLC- $\gamma$ and PI3K, and up-regulation of E2F transcription factors, as well as increased expression of several key components in the $\mathrm{G}_{1} / \mathrm{S}$ transition of the cell cycle, such as cyclins A, D1 and E, CD25 and PCNA (proliferating cell nuclear antigen) [61]. In DRG and SCG neurons, axonal outgrowth was inhibited by the MEK/ERK pathway inhibitor, PD98059 [40]. Chemotaxis of neural progenitors from the brain subventricular zone was mediated by VEGFR2 and was also dependent on an increase in VEGFR2 expression that required the presence of FGF-2 [54].

\section{Role of VEGF Receptor Tyrosine Kinases}

In most of these studies, the effects of VEGF are mediated by VEGFR2 receptors as indicated by expression mains to be determined. Plexins have a large extracellular domain containing short cysteine-rich motifs also found in scatter factor receptors encoded by the MET oncogene family (black boxes), and regions of homology with semaphorins (white box); the plexin intracellular domain contains two separate regions of homology highly conserved within plexins but sharing little homology with other proteins (box and oval). L1 structure comprises an extracellular domain containing 6 Ig-like domains (ovals) and 5 fibronectin type III regions (oblongs), and a large endodomain. Right: It is unknown whether VEGF binding to NP1 is sufficient to trigger intracellular signalling independently of Sema 3A. VEGF has been reported to stimulate activation of PI3K/Akt, PLC- $\gamma$ and MEK/ERK pathways via VEGFR2 in a variety of neuronal cells (see text for details).

of VEGFR2 [40, 44, 45, 48, 56], lack of effect of ligands for other VEGF receptors [45], and effects of VEGFR2 inhibitors or anti-sense oligonucleotides [44, 46, 48, 57, 60]. The signalling pathways thought to be mediated by VEGFR2 in neuronal cells are shown in figure 2. However, the expression of VEGFR1, but not VEGFR2, in hippocampal neuronal membranes was found to correlate with the ability of VEGF to inhibit outward delayedrectifier potassium currents $(I \mathrm{k})[62]$, suggesting that some effects of VEGF in neurons may be VEGFR2-independent.

\section{Role of Neuropilins}

Though VEGF-A 165 binds NP1 and NP2 with high affinity, and NPs have an established role in neuronal patterning and homing, the role of NPs in mediating neuronal functions of VEGFs is presently unclear. Since VEGF$\mathrm{A}_{165}$ and the chemorepulsive factor Sema 3A bind to 
NP1, at least in part, through the same binding site located in the b1/b2 domains of the NP1 extracellular region $[63,64]$, one mechanism for the neurotrophic actions of VEGF- $\mathrm{A}_{165}$ is competitive inhibition of the chemorepellent effects of Sema 3A. Indeed, the balance between Sema $3 \mathrm{~A}$ and VEGF-A 165 , ligands for NP1 with opposing functional effects, may play an important role in regulating axonal guidance and neuronal viability. VEGF-A ${ }_{165}$ enhanced migration, proliferation and survival in the neuroectodermal progenitor cell line, Dev, through antagonism of chemorepulsive and anti-apoptotic effects of Sema 3A mediated via competition for binding to NP1 [55]. Interestingly, this study showed that the chemorepellent effects of Sema 3A also required VEGFR1, consistent with VEGFR1 acting as a 'decoy' or sink, thereby attenuating VEGF-A ${ }_{165}$ activity [4].

Since Sema 3A binding to NP1 also requires the CUB or a1/a2 domains, not all semaphorin-dependent functions of VEGF may be modulated to the same degree by VEGF competition [63]. VEGF also exhibited neuroprotective effects in motor neuron-like NSC34 cells, which were blocked by a combination of neutralising antibodies to VEGFR2 and NP1, indicating a requirement for both receptors [65]. A recent study suggests that NP1 is a key mediator of the anti-chemorepulsive effect of VEGF-A 165 and the NP1 ligand, PlGF-2, in DRG neuronal explants [49]. Interestingly, the specific KDR inhibitor, SU5614, did not affect the anti-chemorepellent effects of VEGF and PlGF-2, while a specific peptide antagonist of VEGF binding to NP1 prevented inhibition of growth cone collapse [49]. These findings suggest that NP1 may have a specific role in mediating neurotrophic actions of VEGF family members in DRG neurons independent of VEGFR2 and VEGFR1.

It is unclear whether neurotrophic effects of VEGF in DRG can be explained solely in terms of inhibition of Sema 3A chemorepulsion, or whether VEGF is able to signal through NP1 in a VEGFR2-independent manner. The signal transduction mechanisms triggered by ligand binding to NP1 remain to be fully delineated, though the small size of the NP1 intracellular domain suggests that it is unable to transduce a functionally productive signal itself and is dependent for signal generation on association with other components (fig. 2). This possibility is underscored by the fact that several NP-binding semaphorins, for example Sema 3A and Sema 3C, can act either as axonal repellents or attractants in different neuronal cell types, suggesting that the type of biological response mediated by NPs is determined by additional signalling components. Most semaphorins bind to their respective plexin receptors directly, but several members of the class 3 semaphorins (Sema 3A, 3C, 3D and 3F) instead bind to NP1 and/or NP2, which forms a signalling complex with plexins A1 or 2, transmembrane proteins with large intracellular domains [66]. How signals are transduced by NP/plexin A complexes is currently unclear, but similarities between the cytoplasmic plexin region and Ras GTPase-activating proteins (GAPs) suggest that plexins may have GAP-like activity towards small GTPases [67]. Consistent with this possibility, recruitment of the small Rho-family GTPase Rnd 1 by plexin A1 is able to trigger cytoskeletal collapse, whereas another GTPase, RhoD, prevents plexin A1 signalling via Rnd1 [68]. Interactions between NP1 and L1, a member of the immunoglobulin superfamily of cell adhesion molecules containing a large endodomain, are also required for Sema 3A-triggered growth cone collapse [69]. L1 may regulate cytoskeletal integrity through direct binding to both actin and ankyrin, a cytoskeleton-associated protein linked to the spectrin-actin network [70]. Another candidate for mediation of NP1-dependent signalling is a PSD-95/Dlg/ ZO-1 (PDZ) domain protein, NP1-interacting protein-1 (NIP-1, identical to synectin and RGS-GAIP-interacting protein (GIPC)), which binds to a canonical carboxyl-terminal PDZ domain-binding motif in NP1 [71]. It is possible, though so far unknown, that VEGF is able to trigger anti-chemorepellent signals by regulating signalling mediated via plexin A or L1, or via NP1 associations with synectin or other PDZ domain proteins (fig. 2).

The different biological roles of semaphorin and VEGF binding to NP1 have been investigated using knock-in mice expressing NP1 variants deficient in binding to semaphorins but retaining the ability to bind VEGF. These mutants perturbed the normal formation of axonal projections in cranial and spinal nerves and exhibited a variety of other effects on neurogenesis, but had none of the vascular defects observed in conditional endothelial cell-specific NP1 knock-out mice [72]. Furthermore, mice expressing NP1 mutants deficient in semaphorin binding had a milder phenotype than NP1-null mice, indicating that some functions of NP1 in the development of the nervous system are independent of semaphorins. While indicating that semaphorin binding to NP1 is not essential for the vascular functions of NP1, these findings also point to a requirement of VEGF binding for some of the neural functions of NP1. It cannot be precluded, however, that NP1 has neural functions mediated via other, so far unidentified, cell surface ligands. NP1 can also mediate cell adhesion via heterophilic cell-cell interactions that have yet to be defined. The b1/b2 domains of NP1 
Fig. 3. Possible roles of VEGF in the coordination of vascular and neural developmental processes. This is a schematic illustration of the possible interactions between VEGF and cells of the peripheral and central nervous systems based on a variety of in vitro and in vivo studies (see text for details). VEGF is produced by both neuronal and glial cells in the developing nervous system and in addition to its prime role in angiogenesis has diverse neurotrophic and neuroproliferative effects on neurons, glia (e.g. astrocytes and Schwann cells) and nerve stem cells (NSC). Direct neurotrophic and neuroprotective effects may be important in some developmental situations and in maintaining neuronal function in adults. In turn, endothelial cells and VSMC in the vasculature produce several neurotrophic factors including BDNF and arte$\mathrm{min}$. The reciprocal effects of neural-derived VEGF and vascular-derived neurotrophic factors may play key roles in the co-ordination of vascular and neural development.

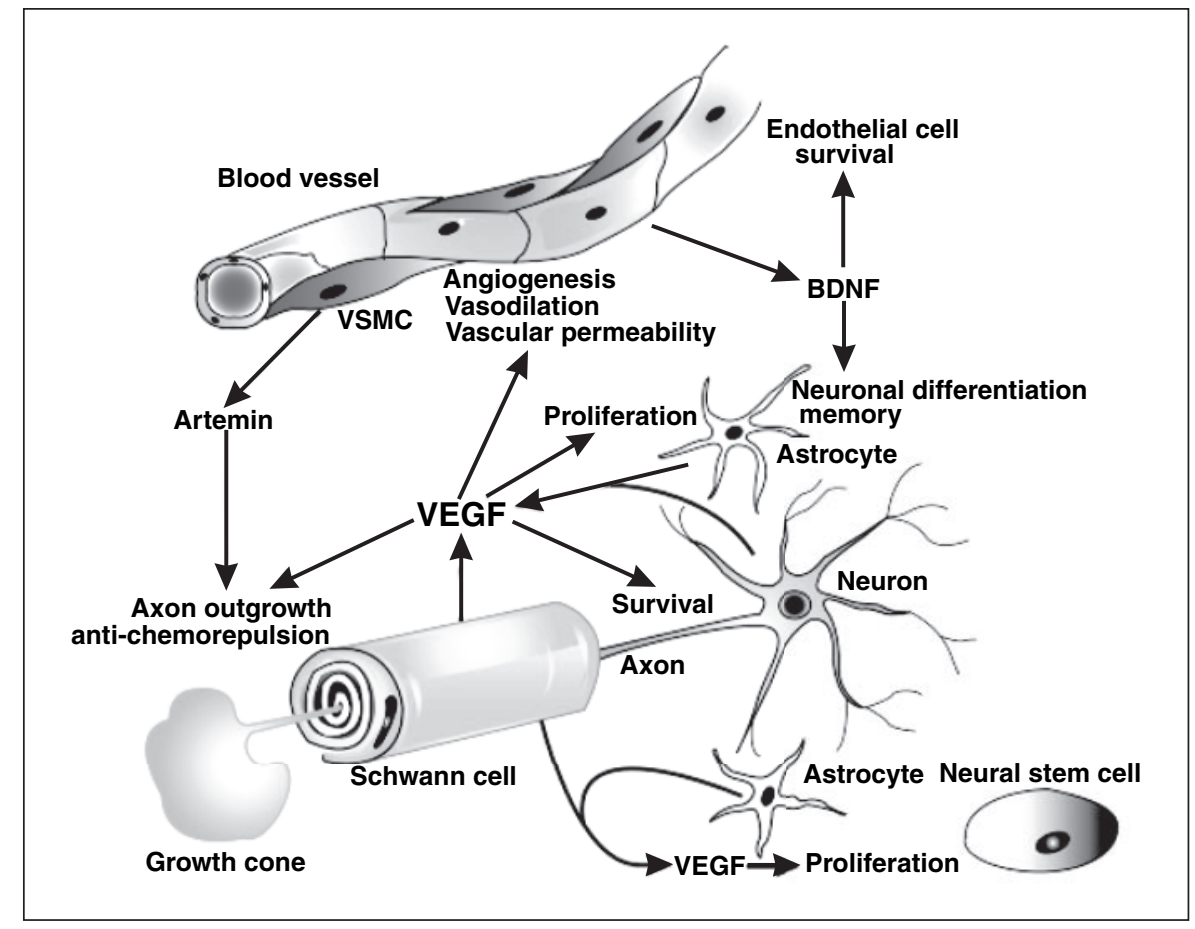

are required for cell adhesion, but the interactions appear to be independent of both class 3 semaphorins and VEGF [73]. NP1 also mediated adhesion of endothelial cells independently of VEGF [74].

\section{Biological Role of Neurotrophic Effects of VEGF}

The nervous and vascular systems are both highly ramified structures that are physically associated and exhibit several striking developmental and anatomical parallels. These similarities raise several questions: Are the branching networks of nerves and blood vessels established independently or co-ordinately? If there is interaction between nerves and vessels, does one or the other play the key determining role, and, if so, what are the essential signals and hierarchical relationships between them? Finally, can endothelial cytokines, such as VEGF, multitask as neurotrophic factors, and vice versa? Recent research has begun to reveal the extent to which neural and vascular development is mechanistically integrated via reciprocal molecular interactions $[75,76]$. The mechanistic links between nervous and vascular systems are illustrated (fig. 3) by the dependence of axonal guidance in the developing sympathetic system on the ability of VSMC in blood vessels adjacent to sympathetic axonal projections to express artemin, a chemoattractive factor of the glial cell line-derived neurotrophic factor (GDNF) family [77].

\section{Role of VEGF in Embryonic Neurogenesis}

Establishment of the relative contributions of VEGFdependent angiogenesis and direct neurotrophic actions of VEGF to neurogenesis and neural function is an inherently difficult problem to address, because angiogenesis is so critical for both development and tissue growth. Largely for this reason, it is unresolved whether VEGF has an important biological role as a direct regulator of neuronal function or development independent of its angiogenic effect. Evidence from mice deficient in VEGF or VEGFRs did not provide clues to the possible neural functions of VEGF, because deficiencies in either the ligand or its two major receptors, VEGFR1 and VEGFR2, caused early embryonic lethality arising from a failure of vasculogenesis [78-81]. Mice expressing only VEGF-A 120 $\left(\right.$ VEGF $\left.^{120 / 120}\right)$ and lacking the larger VEGF- $\mathrm{A}_{165}$ and VEGF-A 188 isoforms, die peri-natally or by post-natal day 14 and display defective myocardial and retinal angiogenesis and ischaemic cardiomyopathy [82-84]. In addition, $\mathrm{VEGF}^{120 / 120}$ mutants also exhibit a range of defects in the patterning of facial branchiomotor neurons due to 
impaired migration of neuronal somata rather than defective axonal guidance and similar to neuronal pathfinding defects found in NP1-deficient mice [85]. Mice expressing only VEGF- $\mathrm{A}_{164}$ were normal and healthy, consistent with the dominant role of this isoform in mediating biological effects of VEGF. The lack of a more severe neural phenotype in mice lacking this isoform may be due to partial compensation by other VEGF isoforms or VEGFrelated factors able to perform similar neurogenic functions.

\section{VEGF and Adult Neurogenesis}

Though the precise role of VEGF in embryonic neurogenesis is unclear, evidence from several vertebrate systems in which neurogenesis occurs in the adult state, indicates that endothelial cells play an essential role by generating a microenvironment, or vascular niche, that promotes the proliferation of NSC. In the hippocampal subgranule zone, a region where neurogenesis occurs throughout adult life, dividing neural progenitors are concentrated in dense clusters around blood vessels, and neurogenesis is tightly co-ordinated with angiogenesis [86]. During neurogenesis in the higher vocal centres of adult songbirds, testosterone induces neurogenesis and endothelial cell proliferation via up-regulation of VEGF and VEGFR2, which stimulate an angiogenic response, leading to increased production of the brain-derived neurotrophic factor (BDNF) by the newly formed vasculature (fig. 3); BDNF, in turn, is able to support subsequent neuronal differentiation [87].

\section{Effects of VEGF in NSC}

As mentioned above, VEGF acting via VEGFR2 promotes the migration, survival and proliferation of neural progenitors [53-55]. However, it is unclear whether VEGF acting directly on NSC, or an indirect effect of VEGF-induced endothelial cell proliferation, plays the more essential role. NSC are preferentially localised in areas contiguous to blood vessels [86-88] and communication between these cell types appears to be essential for maintaining the capacity of NSC for self-renewal, whereas prevention of the interaction is a stimulus for neuronal differentiation [89]. In this study, self-renewal of NSC was dependent both on FGF-2 stimulation of NSC proliferation, and on the production of soluble factors by endothelial cells and activation of Notch1 signalling in NSC.

VEGF is strongly expressed by neural progenitor cells in the ventricular zone of the developing brain, and is a key signal orchestrating vascularisation of the neuroectoderm [76]. The importance of VEGF in brain develop- ment is demonstrated by the finding that conditional homozygous inactivation of VEGF in the neural tube of the developing mouse brain using cre/lox technology caused a severe impairment of brain vascularisation and resulted in massive neuronal apoptosis [90]. This study indicates that VEGF is essential for brain angiogenesis and, either directly or indirectly, for the production of signals necessary for neuronal survival. Together with the other work considered in this section, these findings are consistent with a key role for VEGF, acting in concert with endothelial-derived neurotrophic cytokines, in a signalling network that coordinates angiogenesis and neurogenesis, but it is again unclear whether direct effects of VEGF on neuronal cells are important for mediating its biological role in the brain.

\section{Role of VEGF in Peripheral Nerve Pathfinding}

Contrasting conclusions about the biological role of direct neuronal effects of VEGF have recently come from studies of peripheral nerve development. An earlier investigation found that local ablation of the peripheral nervous system by UV irradiation, did not disrupt the patterning of large vessels in embryonic chick limbs [91]. A re-examination of this question in mouse limb skin showed that peripheral nerves associate preferentially with arteries expressing the arterial marker, ephrin B2, prior to investment of arteries with VSMC. Furthermore, mutations in neurogenins 1 and 2 that cause a loss of peripheral sensory nerves and their associated Schwann cells, impaired the normal branching pattern of blood vessels, resulting in a depletion of intermediate-size branches and reduced expression of markers of arterial differentiation [92]. A requirement of nerve-derived VEGF production for arterial differentiation has been demonstrated by neuron-specific Cre recombinase-mediated knock-out of VEGF in the mouse [93]. Consonant with these findings, either VEGF-A administration, or inhibition of VEGF-A signalling using soluble VEGFR1, perturbed vascularisation of developing forelimbs in quail embryos, but had little effect on the pattern of innervation [94]. Furthermore, inhibition of either VEGFR2 or VEGF sequestration using soluble VEGFR 1 had no effect on axonal outgrowth in embryonic DRG explants while severely disrupting the local capillary network [95]. These studies indicate that while peripheral nerves form a template determining the pattern of vascularisation during vertebrate limb development, VEGF production by glial cells and sensory neurons acts as a key mediator of vascular patterning and arterial differentiation but is not essential for axonal pathfinding. 


\section{Role of VEGF in Invertebrate Neurogenesis}

The discovery of invertebrate VEGF/VEGFR systems promises to yield fresh insights into the biological functions performed by neuronal effects of VEGFs. Four VEGFR-like molecules, VERs (vascular endothelial growth factor receptor related) 1, 2, 3 and 4, have been identified in the nematode worm, Caenorhabditis elegans, which lacks both a vascular circulatory system and blood cells. C. elegans VERs are localized to cells of neural origin, suggesting a role in neurogenesis [96]. Definitive identification of a VER ligand is awaited, although a putative homologue of the Drosophila PDGF/VEGF-like factor, PVF1, was revealed by a survey of the C. elegans genome [96]. In Drosophila, the VEGF/PDGF-like factors, PVFs $1-3$, and their receptor, PVR, play key roles in the migration of border cells during oogenesis and hemocytes (blood cells) in development [97-99]. Disruption of PVR function in Drosophila causes defects in both CNS axon tract morphology and positioning of glial cells, though this appears to be mediated indirectly by a failure of macrophages to migrate to the CNS and engulf apoptotic neural cell corpses rather than through the loss of a direct neurogenic role of the PVF/PVR axis [100]. VEGF and VEGFR genes are expressed in tubular structures of the gastrovascular system of the jellyfish, Podocoryne carnea [101], a member of Cnidaria, the simplest invertebrate phylum of the animal kingdom possessing tissue organization and a complex neural network. P. carnea VEGF/VEGFRs are also present in the endoderm when undifferentiated cells migrate and differentiate into plate cells, suggestive of a role in cell migration or homing. These findings suggest that VEGF and VEGFR-like molecules may have been co-opted to perform roles in neural development of some invertebrate species, but they also indicate that they may have had more general roles in cell migration and the formation of tubular structures in diverse developmental contexts, evolutionarily antecedent to the emergence of a vascular system.

\section{Therapeutic Potential of VEGF for Neural Disease}

\section{Cerebral and Peripheral Nerve Ischaemia}

VEGF is strongly implicated in mediating the vascular response to cerebral ischaemia resulting from stroke. Expression of VEGF, its receptors, VEGFR1 and VEGFR2, and the key hypoxia-inducible transcription factor, HIF$1 \alpha$, is induced by focal ischaemia in the rat brain [102-106]; furthermore, hypoxia-inducible expression of
VEGF, VEGFR1 and VEGFR2 precedes neovascularisation following cerebral ischaemia [107]. The ability of VEGF both to stimulate angiogenesis and to elicit direct neurotrophic effects makes it an attractive candidate for repair or regeneration of nerves damaged by ischaemic disease. In support of such a protective role, inhibition of VEGF increased brain infarct size in ischaemia [103] and also delayed brain repair following injury [108]. However, VEGF up-regulation following cerebral ischaemia may have deleterious effects due to its permeability-increasing activity. VEGF production by tumourigenic glioblastoma cells causes intracerebral haemorrhage resulting from the formation of unstable vessels [109], while VEGF antagonism has been shown to reduce brain oedema, tissue damage and blood-brain barrier leakage after ischaemia/reperfusion injury in animal models [110, 111]. Both the timing of VEGF treatment and the route of delivery seem to be important determinants of its therapeutic effect in cerebral ischaemia. While late $(48 \mathrm{~h}$ post-ischaemia) intravenous administration of VEGF enhanced angiogenesis and significantly improved neurological recovery, early treatment with VEGF (1 h postischaemia) increased brain-blood barrier leakage, haemorrhagic transformation and ischaemic lesions [111]. Administration of VEGF either by topical application to the brain surface, or by intracerebroventricular infusion reduced brain oedema and infarct volume [112, 113], though this was dependent on the concentration used [114]. The neuroprotective effect of intracerebroventricular infusion was associated with increased angiogenesis, and both acute and longer term enhancement of neuronal survival [115]. There may also be a role for other VEGF family members in protection against ischaemic brain damage. Augmented cerebral ischaemic injury was reported in VEGF-B-deficient mice [116], and PlGF expression was up-regulated following cerebral ischaemia in mice, while NP1 was also highly expressed in vessels and neurons [117].

VEGF may also have therapeutic potential for the treatment of peripheral nerve disease. Peripheral neuropathy is a common complication of diabetes and critical limb ischaemia, resulting in part from hypoxic damage to the vasa nervorum and consequent sensory deficits in the lower extremities. VEGF gene transfer restored peripheral nerve function in streptozotocin-induced diabetic neuropathy [118] and hindlimb ischaemia [119].

Though it is attractive to postulate a direct neuroregenerative role of VEGF, it is difficult in many of these examples to assess whether neural repair or neuroprotection are the results of a direct neurotrophic effect, or are 
secondary to VEGF-driven angiogenesis and hence improved perfusion of the ischaemic territory. However, a recent study suggests that in mice transgenically overexpressing VEGF specifically in the brain, protection against cerebral ischaemia may not significantly benefit from the effects of VEGF-driven angiogenesis but instead is largely due to a direct neuroprotective effect resulting from inhibition of apoptotic pathways such as caspase- 3 activation [120]. Though mice overexpressing VEGF had a constitutively greater cerebral vessel density that was associated with enhanced overall cerebral blood flow, blood flow to the ischaemic territory was actually reduced [120].

\section{Nerve Repair}

VEGF has also been investigated for its ability to promote nerve repair following spinal injury. Expression of VEGF and its receptors are increased in lesions caused by traumatic injury to the spinal cord $[121,122]$. VEGF stimulated axonal regeneration in preparations of sciatic nerves in vitro [123], and adenoviral VEGF administration promoted regeneration of corticospinal tract axons in rats following transection of the spinal cord [124]. Following traumatic spinal injury, treatment with recombinant VEGF $_{165}$ also caused an improvement in recovery, associated with increased vessel density and reduced apoptosis in the lesion area, and increased expression of VEGFR1, VEGFR2, NP1 and NP2 [125]. However, VEGF-A 165 therapy was also found to have a worsening effect on the lesions caused by spinal cord injury possibly secondary to its effect on vascular permeability [126].

\section{Neurodegenerative Disease}

Perhaps the strongest evidence that a direct neuronal effect of VEGF is biologically important for normal function of adult nerves has come from studies of the rare neurodegenerative disease, amyotrophic lateral sclerosis (ALS), also called Charcot or Lou Gehrig's disease. ALS is a progressive neurodegenerative disorder resulting from the selective death of motor neurons, and usually fatal within $1-5$ years of onset $[127,128]$. The disease affects $1-2$ per 100,000 people, $>90 \%$ of cases having no known cause or genetic linkage, and referred to as sporadic ALS. Approximately 5-10\% of cases are familial, and of these, $20 \%$ are thought to be caused by mutations in the enzyme superoxide dismutase-1 (SOD1). Transgenic expression of SOD1 mutants causes an ALS-like disease in mice, and is associated with a dramatic increase in SOD1 activity, suggesting that the pathogenesis involves a toxic effect of gain-of-function SOD1 mutants
[128]. The first indication of a role for VEGF in ALS was the discovery that homozygous deletion of the hypoxiaresponse element in the VEGF promoter in mice $\left(\mathrm{HRE}^{-/-}\right)$resulted after 5 months in the development of motor neuron degeneration and other neuropathological features characteristic of mouse models of ALS and ALS patients, such as specific depletion of choline-acetyltransferase-positive neurons, occurrence of neurofilament inclusions and selective loss of large myelinated motor neurons [65]. HRE deletion caused a subtle tissue-specific loss of hypoxia-inducible VEGF expression in neural tissue, accounting for the lack of a more severe phenotype in these mice that would result from a more general loss of VEGF expression [65]. The adult-onset ALS-like disease observed in $\mathrm{HRE}^{-/-}$mice was, at least in part, secondary to impaired neural vascular perfusion, though this was not caused by any apparent defect in vascularisation. Hypoxic induction of VEGF was also impaired in mice expressing SOD1 mutants [129]. The relevance of VEGF for human ALS is suggested by the finding that individuals homozygous for certain polymorphisms in the VEGF promoter have a significantly increased risk of ALS (1.8 times greater), associated with decreased circulating levels of VEGF and reduced VEGF gene expression [130]. Though mice expressing SOD1 mutants develop ALSlike symptoms and die more rapidly than $\mathrm{HRE}^{-/-}$mice, 'knock-in' of the HRE deletion in SOD $1^{\mathrm{G} 93 \mathrm{~A}}$ mice reduced survival still further [130]. Consistent with a direct motor neuron effect of VEGF in ameliorating ALS-like symptoms, neuronal overexpression of VEGFR2 delayed onset of disease in SOD $1^{\mathrm{G} 93 \mathrm{~A}}$ mice [131], while VEGF protected cultured motor neuron-like NSC 34 cells against cell death [65]. The findings that intracerebroventricular VEGF protein administration delayed onset and improved survival in a SOD $1^{\mathrm{G} 93 \mathrm{~A}}$ rat model, while VEGF gene delivery using a lentiviral vector delayed the onset and progression of ALS-like disease in SOD $1^{\mathrm{G} 93 \mathrm{~A}}$ transgenic mice $[131,132]$, suggest that VEGF therapy might have potential for the treatment of this currently incurable disease.

Further evidence supporting a role of endogenous VEGF in protecting motor neurons against degenerative disease has come from a mouse model of X-linked spinobulbar muscular atrophy (SBMA or Kennedy's disease), a rare inherited neuromuscular disease characterised by degeneration of lower motor neurons, and caused by a polyglutamine repeat expansion in the androgen receptor (AR). Transgenic overexpression of an AR gene carrying the polyglutamine-encoding repeat $(\mathrm{CAG})$ recapitulated key features of human SBMA, and resulted in impaired 
VEGF expression, while VEGF rescued motor neuronlike cells (a hybrid of motor neurons and neuroblastoma cells) from death induced by AR polyglutamine constructs [133].

While much less is known regarding the role of VEGF in common chronic neurodegenerative diseases, vascular pathologies are recognised to play an important role in the most common forms of dementia. There is strong evidence that in a substantial proportion of cases, the pathogenesis of Alzheimer's disease (AD) involves an angiopathy characterised by irregularities in arterial wall structure and an increased capillary density associated with $\beta$-amyloid peptide deposits $[134,135]$. Vascular dementia (VD), the second most common form of age-related dementia, is thought to result from multiple brain infarcts leading to loss of brain tissue [136, 137]. A high proportion of $\mathrm{AD}$ patients also show evidence of cerebrovascular disease [137]. These findings implicate VEGF as a potential mediator of pathological neovascularisation induced either by $\beta$-amyloid peptide signalling or in response to cerebral ischaemia. Increased VEGF immunoreactivity is observed in the neocortical astrocytes and large intraparenchymal vessels of AD patients [138], and VEGF and FGF-2 are also present in the choroid plexus in $\mathrm{AD}$ [139]. Intrathecal levels of VEGF were also elevated in AD and VD patients and these were related to the severity of the disease [140]. Genome-wide expression profiling of AD brain mRNA reveals a generalised depression of gene expression accompanied by up-regulation of a specific subset of genes encoding for pro-apoptotic, proinflammatory and pro-angiogenic proteins, including the cell death receptor, FAS, interleukin- $1 \beta, \mathrm{COX}-2$ and VEGF [141, 142]. Accumulation of VEGF also colocalised with $\beta$-amyloid deposits in the brains of $\mathrm{AD}$ patients [143].

There is some evidence suggesting that VEGF could have a protective role against the selective degeneration of dopaminergic neurons in Parkinson's disease. Thus, VEGF had a neuroprotective effect against the death of dopaminergic neurons induced by 6-hydroxydopamine both in culture and in a mouse model [144].

\section{Conclusions and Perspectives}

There is growing evidence that the mechanisms controlling development of the neural and cardiovascular systems intermesh to a remarkable degree. Members of the neuropilin, semaphorin and plexin families, originally thought to be primarily regulators of axonal guidance, are also critically important for several aspects of cardiovascular development. In addition to the vascular defects found in NP knock-out mice, targeted disruption of Sema 3C results in impaired development of the aorta [145], while Sema 6D signalling via plexin A1 plays a key role in cardiac morphogenesis [146], and genetic ablation of Sema $3 \mathrm{E}$ and its receptor plexin D1 disrupts embryonic intersomitic vascular patterning [21]. Conversely, VEGFA, once identified as a specific endothelial cytokine, is now well established to exert direct neuroprotective, neurotrophic and neuroproliferative effects in a variety of neural cell types in culture, and promote both neurogenesis and neuroprotection in animal models of cerebral ischaemia, neurodegenerative diseases and traumatic nerve injury. Tyrosine kinase receptors for VEGF are expressed in neural tissue, and specific isoforms of VEGF-A and other VEGF family members bind with high affinity to NP1 and/or NP2. Though many details of the mechanisms underlying direct neuronal effects of VEGF remain to be determined, VEGF induces a variety of early signalling events in neurons, and at least some neuronal effects of VEGF are mediated by VEGFR2 and/or NP1. New modalities of VEGF signalling relevant for neuronal and vascular systems are also continuing to emerge, as illustrated by mediation of the role of Sema 6D in cardiac morphogenesis via complexes of plexin A1 and VEGFR2 [146].

Despite the abundant and compelling evidence that VEGF can promote both direct and indirect effects on neuronal cells, there has remained a considerable degree of uncertainty regarding the physiological importance of these effects either during development or in the adult. While endothelial cells and angiogenesis play key roles in neural development, and may be particularly important in providing signals necessary for the self-renewal of NSC, the precise roles of angiogenesis and direct neurotrophic effects of VEGF either during embryonic or adult neurogenesis, or in protective responses to ischaemia and adult nerve injury, remain unclear. However, evidence from recent studies of mice specifically lacking the most abundant and biologically active VEGF isoform, VEGF-A ${ }_{165}$, indicate that it plays an important role in the migration and pathfinding of some embryonic nerves. VEGF has also shown promise in animal studies as a potential future therapy for nerve damage caused by spinal cord injury, cerebral ischaemia and in the rare neurodegenerative disease, ALS. Though the potent vascular permeability-increasing effect of VEGF is a potential obstacle to harnessing its therapeutic potential in nerve disorders, the experience of VEGF clinical trials for cardiovascular disease 
suggests that, in humans at least, VEGF therapy is safe and well tolerated. If results in animal studies can be replicated in humans, VEGF may emerge as an alternative treatment for neurodegenerative disease in the future.

\section{Acknowledgement}

The author acknowledges research funding from the British Heart Foundation.

\section{References}

- 1 Senger DR, Galli SJ, Dvorak AM, Perruzzi CA, Harvey VS, Dvorak HF: Tumor cells secrete a vascular permeability factor that promotes accumulation of ascites fluid. Science 1983;219:983-985.

$\checkmark 2$ Leung DW, Cachianes G, Kuang WJ, Goeddel DV, Ferrara N: Vascular endothelial growth factor is a secreted angiogenic mitogen. Science 1989:246:1306-1309.

-3 Keck PJ, Hauser SD, Krivi G, Sanzo K, Warren T, Feder J, Connolly DT: Vascular permeability factor, an endothelial cell mitogen related to PDGF. Science 1989;246:1309-1312.

-4 Ferrara N, Gerber HP, LeCouter J: The biology of VEGF and its receptors. Nat Med 2003; 9:669-676.

-5 Robinson CJ, Stringer SE: The splice variants of vascular endothelial growth factor and their receptors. J Cell Sci 2001;114:853-865.

-6 Holmes DI, Zachary I: The vascular endothelial growth factor family: angiogenic factors in health and disease. Genome Biol 2005;6:209.

7 Li X, Eriksson U: Novel VEGF family members. VEGF-B, VEGF-C and VEGF-D. Int $\mathrm{J}$ Biochem Cell Biol 2001;33:421-426.

-8 Shibuya M: Vascular endothelial growth factor receptor-2: its unique signalling and specific ligand, VEGF-E. Cancer Sci 2003;94:751-756.

-9 Neufeld G, Cohen T, Gengrinovitch S, Poltorak Z: Vascular endothelial growth factor and its receptors. FASEB J 1999;13:9-22.

10 Zachary I: VEGF signalling: integration and multitasking in endothelial cell biology. Biochem Soc Trans 2003;31:1171-1177.

-11 Soker S, Takashima S, Miao HQ, Neufeld G, Klagsbrun M: Neuropilin-1 is expressed by endothelial and tumor cells as an isoform-specific receptor for vascular endothelial growth factor. Cell 1998;92:735-745.

-12 Migdal M, Huppertz B, Tessler S, Comforti A, Shibuya M, Reich R, Baumann H, Neufeld G: Neuropilin-1 is a placenta growth factor- 2 receptor. J Biol Chem 1998;273:22272-22278.

13 Makinen T, Olofsson B, Karpanen T, Hellman U, Soker S, Klagsbrun M, Eriksson U, Alitalo $\mathrm{K}$ : Differential binding of vascular endothelial growth factor $\mathrm{B}$ splice and proteolytic isoforms to neuropilin-1. J Biol Chem 1999;274:2121721222.

14 Gluzman-Poltorak Z, Cohen T, Herzog Y, Neufeld G: Neuropilin-2 and neuropilin-1 are receptors for the 165-amino acid form of vascular endothelial growth factor (VEGF) and of placenta growth factor-2, but only neuropilin-2 functions as a receptor for the 145-amino acid form of VEGF. J Biol Chem 2000;275:1804018045.
$15 \mathrm{He}$ Z, Tessier-Lavigne M: Neuropilin is a receptor for the axonal chemorepellent Semaphorin III. Cell 1997;90:739-751.

16 Kolodkin AL, Levengood DV, Rowe EG, Tai YT, Giger RJ, Ginty DD: Neuropilin is a semaphorin III receptor. Cell 1997;90:753-762.

$\checkmark 17$ Fujisawa H, Kitsukawa T, Kawakami A, Takagi S, Shimizu M, Hirata T: Roles of a neuronal cell-surface molecule, neuropilin, in nerve fiber fasciculation and guidance. Cell Tissue Res 1997;290:465-470.

18 Chen H, Chedotal A, He Z, Goodman CS, Tessier-Lavigne M: Neuropilin-2, a novel member of the neuropilin family, is a high affinity receptor for the semaphorins Sema E and Sema IV but not Sema III. Neuron 1997;19:547-559.

19 Chen H, He Z, Bagri A, Tessier-Lavigne M: Semaphorin-neuropilin interactions underlying sympathetic axon responses to class III semaphorins. Neuron 1998;21:1283-1290.

20 Giger RJ, Urquhart ER, Gillespie SK, Levengood DV, Ginty DD, Kolodkin AL: Neuropilin-2 is a receptor for semaphorin IV: insight into the structural basis of receptor function and specificity. Neuron 1998;21:1079-1092.

21 Gu C, Yoshida Y, Livet J, Reimert DV, Mann F, Merte J, Henderson CE, Jessell TM, Kolodkin AL, Ginty DD: Semaphorin 3E and plexinD1 control vascular pattern independently of neuropilins. Science 2005;307:265-268.

22 Kitsukawa T, Shimono A, Kawakami A, Kondoh $\mathrm{H}$, Fujisawa $\mathrm{H}$ : Overexpression of a membrane protein, neuropilin, in chimeric mice causes anomalies in the cardiovascular system, nervous system and limbs. Development 1995; 121:4309-4318.

23 Kawasaki T, Kitsukawa T, Bekku Y, Matsuda Y, Sanbo M, Yagi T, Fujisawa H: A requirement for neuropilin-1 in embryonic vessel formation. Development 1999;126:4895-4902.

24 Takashima S, Kitakaze M, Asakura M, Asanuma H, Sanada S, Tashiro F, Niwa H, Miyazaki Ji J, Hirota S, Kitamura Y, Kitsukawa T, Fujisawa H, Klagsbrun M, Hori M: Targeting of both mouse neuropilin-1 and neuropilin2 genes severely impairs developmental yolk sac and embryonic angiogenesis. Proc Natl Acad Sci USA 2002; 99:3657-3662.

26 Millauer B, Wizigmann-Voos S, Schnurch H, Martinez R, Moller NP, Risau W, Ullrich A: High affinity VEGF binding and developmental expression suggest Flk-1 as a major regulator of vasculogenesis and angiogenesis. Cell 1993; 72:835-846.

- 27 Breier G, Clauss M, Risau W: Coordinate expression of vascular endothelial growth factor receptor-1 (flt-1) and its ligand suggests a paracrine regulation of murine vascular development. Dev Dyn 1995;204:228-239.

28 Ogunshola OO, Stewart WB, Mihalcik V, Solli T, Madri JA, Ment LR: Neuronal VEGF expression correlates with angiogenesis in postnatal developing rat brain. Brain Res Dev Brain Res 2000;119:139-153.

29 Monacci WT, Merrill MJ, Oldfield EH: Expression of vascular permeability factor/vascular endothelial growth factor in normal rat tissues. Am J Physiol 1993;264:C995-C1002.

30 Naito S, Chang L, Pettigrew K, Ishihara S, Brightman M: Conditions that may determine blood vessel phenotype in tissues grafted to brain. Exp Neurol 1995;134:230-243.

-31 Ferrara N, Houck K, Jakeman L, Leung DW: Molecular and biological properties of the vascular endothelial growth factor family of proteins. Endocr Rev 1992;13:18-32.

32 Stone J, Itin A, Alon T, Pe'er J, Gnessin H, Chan-Ling T, Keshet E: Development of retinal vasculature is mediated by hypoxia-induced vascular endothelial growth factor expression by neuroglia. J Neurosci $1995 ; 15$ : 4738-4747.

33 Ijichi A, Sakuma S, Tofilon PJ: Hypoxia-induced vascular endothelial growth factor expression in normal rat astrocyte cultures. Glia 1995; 14:87-93.

-34 Sinor AD, Irvin SM, Cobbs CS, Chen J, Graham SH, Greenberg DA: Hypoxic induction of vascular endothelial growth factor protein in astroglial cultures. Brain Res 1998;812:289_ 291.

35 Bartholdi D, Rubin BP, Schwab ME: VEGF mRNA induction correlates with changes in the vascular architecture upon spinal cord damage in the rat. Eur J Neurosci 1997;9: 2549-2560

25 Dumont DJ, Fong GH, Puri MC, Gradwohl G, Alitalo K, Breitman ML: Vascularization of the mouse embryo: a study of flk-1, tek, tie, and vascular endothelial growth factor expression during development. Dev Dyn 1995;203:8092.

36 Krum JM, Rosenstein JM: VEGF mRNA and its receptor flt-1 are expressed in reactive astrocytes following neural grafting and tumor cell implantation in the adult CNS. Exp Neurol 1998; 154:57-65.

37 Samii A, Unger J, Lange W: Vascular endothelial growth factor expression in peripheral nerves and dorsal root ganglia in diabetic neuropathy in rats. Neurosci Lett 1999;262:159-162. 
-38 Rosenstein JM, Mani N, Silverman WF, Krum JM: Patterns of brain angiogenesis after vascular endothelial growth factor administration in vitro and in vivo. Proc Natl Acad Sci USA 1998;95:7086-7091.

-39 Silverman WF, Krum JM, Mani N, Rosenstein JM: Vascular, glial and neuronal effects of vascular endothelial growth factor in mesencephalic explant cultures. Neuroscience 1999;90: 1529-1541.

-40 Sondell M, Lundborg G, Kanje M: Vascular endothelial growth factor has neurotrophic activity and stimulates axonal outgrowth, enhancing cell survival and Schwann cell proliferation in the peripheral nervous system. J Neurosci 1999; 19:5731-5740.

-41 Sondell M, Lundborg G, Kanje M: Vascular endothelial growth factor stimulates Schwann cell invasion and neovascularization of acellular nerve grafts. Brain Res 1999;846:219_ 228.

-42 Forstreuter F, Lucius R, Mentlein R: Vascular endothelial growth factor induces chemotaxis and proliferation of microglial cells. J Neuroimmunol 2002;132:93-98.

$\checkmark 43$ Zhu Y, Jin K, Mao XO, Greenberg DA: Vascular endothelial growth factor promotes proliferation of cortical neuron precursors by regulating E2F expression. FASEB J 2003; 17: 186-193.

-44 Jin K, Zhu Y, Sun Y, Mao XO, Xie L, Greenberg DA: Vascular endothelial growth factor stimulates neurogenesis in vitro and in vivo. Proc Natl Acad Sci USA 2002;99:11946-11950.

- 45 Jin KL, Mao XO, Greenberg DA: Vascular endothelial growth factor: direct neuroprotective effect in in vitro ischemia. Proc Natl Acad Sci USA 2000;97:10242-10247.

- 46 Matsuzaki H, Tamatani M, Yamaguchi A, Namikawa K, Kiyama H, Vitek MP, Mitsuda $\mathrm{N}$, Tohyama M: Vascular endothelial growth factor rescues hippocampal neurons from glutamate-induced toxicity: signal transduction cascades. FASEB J 2001;15:1218-1220.

47 Qiu MH, Zhang R, Sun FY: Enhancement of ischemia-induced tyrosine phosphorylation of $\mathrm{Kv} 1.2$ by vascular endothelial growth factor via activation of phosphatidylinositol 3-kinase. J Neurochem 2003;87:1509-1517.

-48 Sondell M, Sundler F, Kanje M: Vascular endothelial growth factor is a neurotrophic factor which stimulates axonal outgrowth through the flk-1 receptor. Eur J Neurosci 2000;12:42434254.

-49 Cheng L, Jia H, Löhr M, Bagherzadeh A, Holmes DIR, Selwood D, Zachary I: Anti-chemorepulsive effects of vascular endothelial growth factor and placental growth factor-2 in dorsal root ganglion neurons are mediated via neuropilin-1 and cyclooxygenase-derived prostanoid production. J Biol Chem 2004;279: 30654-30661.

- 50 Bocker-Meffert S, Rosenstiel P, Rohl C, Warneke N, Held-Feindt J, Sievers J, Lucius R: Erythropoietin and VEGF promote neural outgrowth from retinal explants in postnatal rats. Invest Ophthalmol Vis Sci 2002;43:20212026.
51 Yang K, Cepko CL: Flk-1, a receptor for vascular endothelial growth factor, is expressed by retinal progenitor cells. J Neurosci 1996;16: 6089-6099.

-52 Maurer MH, Tripps WK, Feldmann RE Jr, Kuschinsky W: Expression of vascular endothelial growth factor and its receptors in rat neural stem cells. Neurosci Lett 2003;344: 165-168.

-53 Schanzer A, Wachs FP, Wilhelm D, Acker T, Cooper-Kuhn C, Beck H, Winkler J, Aigner L, Plate KH, Kuhn HG: Direct stimulation of adult neural stem cells in vitro and neurogenesis in vivo by vascular endothelial growth factor. Brain Pathol 2004;14:237-248.

-54 Zhang H, Vutskits L, Pepper MS, Kiss JZ: VEGF is a chemoattractant for FGF-2-stimulated neural progenitors. J Cell Biol 2003;163: 1375-1384.

55 Bagnard D, Vaillant C, Khuth ST, Dufay N, Lohrum M, Puschel AW, Belin MF, Bolz J, Thomasset N: Semaphorin 3A-vascular endothelial growth factor- 165 balance mediates migration and apoptosis of neural progenitor cells by the recruitment of shared receptor. J Neurosci 2001;21:3332-3341.

56 Jin KL, Mao XO, Greenberg DA: Vascular endothelial growth factor rescues HN33 neural cells from death induced by serum withdrawal. J Mol Neurosci 2000;14:197-203.

57 Wick A, Wick W, Waltenberger J, Weller M, Dichgans J, Schulz JB: Neuroprotection by hypoxic preconditioning requires sequential activation of vascular endothelial growth factor receptor and Akt. J Neurosci 2002;22:64016407.

58 Jin K, Mao XO, Batteur SP, McEachron E, Leahy A, Greenberg DA: Caspase-3 and the regulation of hypoxic neuronal death by vascular endothelial growth factor. Neuroscience 2001;108:351-358.

59 Svensson B, Peters M, Konig HG, Poppe M, Levkau B, Rothermundt M, Arolt V, Kogel D, Prehn JH: Vascular endothelial growth factor protects cultured rat hippocampal neurons against hypoxic injury via an antiexcitotoxic, caspase-independent mechanism. J Cereb Blood Flow Metab 2002;22:1170-1175.

60 Ogunshola OO, Antic A, Donoghue MJ, Fan SY, Kim H, Stewart WB, Madri JA, Ment LR: Paracrine and autocrine functions of neuronal vascular endothelial growth factor in the central nervous system. J Biol Chem 2002;277: 11410-11415.

61 Zhu Y, Jin K, Mao XO, Greenberg DA: Vascular endothelial growth factor promotes proliferation of cortical neuron precursors by regulating E2F expression. FASEB J 2003;17: $186-193$.

62 Xu JY, Zheng P, Shen DH, Yang SZ, Zhang LM, Huang YL, Sun FY: Vascular endothelial growth factor inhibits outward delayed-rectifier potassium currents in acutely isolated hippocampal neurons. Neuroscience 2003;118: 59-67.
$63 \mathrm{Gu}$ C, Limberg BJ, Whitaker GB, Perman B, Leahy DJ, Rosenbaum JS, Ginty DD, Kolodkin AL: Characterization of neuropilin-1 structural features that confer binding to semaphorin $3 \mathrm{~A}$ and vascular endothelial growth factor 165. J Biol Chem 2002;277:18069-18076.

-64 Mamluk R, Gechtman Z, Kutcher ME, Gasiunas N, Gallagher J, Klagsbrun M: Neuropilin-1 binds vascular endothelial growth factor 165 , placenta growth factor- 2 , and heparin via its b1b2 domain. J Biol Chem 2002;277: 24818-24825.

65 Oosthuyse B, Moons L, Storkebaum E, Beck $\mathrm{H}$, Nuyens D, Brusselmans K, Van Dorpe J, Hellings P, Gorselink M, Heymans S, Theilmeier G, Dewerchin M, Laudenbach V, Vermylen P, Raat H, Acker T, Vleminckx V, Van Den Bosch L, Cashman N, Fujisawa H, Drost MR, Sciot R, Bruyninckx F, Hicklin DJ, Ince C, Gressens P, Lupu F, Plate KH, Robberecht W, Herbert JM, Collen D, Carmeliet P: Deletion of the hypoxia-response element in the vascular endothelial growth factor promoter causes motor neuron degeneration. Nat Genet 2001;28:131-138.

-66 Takahashi T, Fournier A, Nakamura F, Wang LH, Murakami Y, Kalb RG, Fujisawa H, Strittmatter SM: Plexin-neuropilin-1 complexes form functional semaphorin-3A receptors. Cell 1999;99:59-69.

67 Rohm B, Rahim B, Kleiber B, Hovatta I, Puschel AW: The semaphorin 3A receptor may directly regulate the activity of small GTPases. FEBS Lett 2000;486:68-72.

-68 Zanata SM, Hovatta I, Rohm B, Puschel AW: Antagonistic effects of Rndl and RhoD GTPases regulate receptor activity in semaphorin 3A-induced cytoskeletal collapse. J Neurosci 2002;22:471-477.

69 Castellani V, Chedotal A, Schachner M Faivre-Sarrailh C, Rougon G: Analysis of the L1-deficient mouse phenotype reveals crosstalk between Sema3A and L1 signaling pathways in axonal guidance. Neuron 2000;27: 237-249.

70 Kamiguchi H, Lemmon V: Neural cell adhesion molecule L1: signaling pathways and growth cone motility. J Neurosci Res 1997;49: $1-8$.

71 Cai H, Reed RR: Cloning and characterization of neuropilin-1-interacting protein: a PSD-95/ $\mathrm{Dlg} / \mathrm{ZO}-1$ domain-containing protein that interacts with the cytoplasmic domain of neuropilin-1. J Neurosci 1999;19:6519-6527.

72 Gu C, Rodriguez ER, Reimert DV, Shu T, Fritzsch B, Richards LJ, Kolodkin AL, Ginty DD: Neuropilin-1 conveys semaphorin and VEGF signaling during neural and cardiovascular development. Dev Cell 2003;5:45-57.

73 Shimizu M, Murakami Y, Suto F, Fujisawa H: Determination of cell adhesion sites of neuropilin-1. J Cell Biol 2000;148:1283-1293.

74 Murga M, Fernandez-Capetillo O, Tosato G: Neuropilin-1 regulates attachment in human endothelial cells independently of vascular endothelial growth factor receptor-2. Blood 2005; 105:1992-1999. 
-75 Shima DT, Mailhos C: Vascular developmental biology: Getting nervous. Curr Opin Genet Dev 2000; 10:536-542.

76 Carmeliet P: Blood vessels and nerves: common signals, pathways and diseases. Nat Rev Genet 2003;4:710-720.

-77 Honma Y, Araki T, Gianino S, Bruce A, Heuckeroth R, Johnson E, Milbrandt J: Arte$\mathrm{min}$ is a vascular-derived neurotropic factor for developing sympathetic neurons. Neuron 2002;35:267-282.

-78 Carmeliet P, Ferreira V, Breier G, Pollefeyt S, Kieckens L, Gertsenstein M, Fahrig M, Vandenhoeck A, Harpal K, Eberhardt C, Declercq C, Pawling J, Moons L, Collen D, Risau W, Nagy A: Abnormal blood vessel development and lethality in embryos lacking a single VEGF allele. Nature 1996;380:435-439.

-79 Ferrara N, Carver-Moore K, Chen H, Dowd M, Lu L, O'Shea KS, Powell-Braxton L, Hillan KJ, Moore MW: Heterozygous embryonic lethality induced by targeted inactivation of the VEGF gene. Nature 1996;380:439-442.

-80 Shalaby F, Rossant J, Yamaguchi TP, Gertsenstein M, Wu XF, Breitman ML, Schuh AC: Failure of blood-island formation and vasculogenesis in Flk-1-deficient mice. Nature 1995; 376:62-66.

-81 Fong GH, Rossant J, Gersenstein M, Breitman ML: Role of the Flt-1 receptor tyrosine kinase in regulating the assembly of vascular endothelium. Nature 1995;376:66-70.

\$2 Carmeliet P, Ng YS, Nuyens D, Theilmeier G, Brusselmans K, Cornelissen I, Ehler E, Kakkar VV, Stalmans I, Mattot V, Perriard JC, Dewerchin M, Flameng W, Nagy A, Lupu F, Moons L, Collen D, D'Amore PA, Shima DT: Impaired myocardial angiogenesis and ischemic cardiomyopathy in mice lacking the vascular endothelial growth factor isoforms VEGF164 and VEGF188. Nat Med 1999;5:495-502.

-83 Maes C, Carmeliet P, Moermans K, Stockmans I, Smets N, Collen D, Bouillon R, Carmeliet G: Impaired angiogenesis and endochondral bone formation in mice lacking the vascular endothelial growth factor isoforms VEGF164 and VEGF188. Mech Dev 2002; 111:61-73.

84 Stalmans I, Ng YS, Rohan R, Fruttiger M, Bouche A, Yuce A, Fujisawa H, Hermans B, Shani M, Jansen S, Hicklin D, Anderson DJ, Gardiner T, Hammes HP, Moons L, Dewerchin M, Collen D, Carmeliet P, D'Amore PA: Arteriolar and venular patterning in retinas of mice selectively expressing VEGF isoforms. J Clin Invest 2002;109:327-336.

- 85 Schwarz Q, Gu C, Fujisawa H, Sabelko K, Gertsenstein M, Nagy A, Taniguchi M, Kolodkin AL, Ginty DD, Shima DT, Ruhrberg C: Vascular endothelial growth factor controls neuronal migration and cooperates with Sema3A to pattern distinct compartments of the facial nerve. Genes Dev 2004;18:28222834.

-86 Palmer TD, Willhoite AR, Gage FH: Vascular niche for adult hippocampal neurogenesis. J Comp Neurol 2000;425:479-494.
87 Louissaint A Jr, Rao S, Leventhal C, Goldman SA: Coordinated interaction of neurogenesis and angiogenesis in the adult songbird brain. Neuron 2002;34:945-960.

88 Wurmser AE, Palmer TD, Gage FH: Neuroscience. Cellular interactions in the stem cell niche. Science 2004;304:1253-1255.

-89 Shen Q, Goderie SK, Jin L, Karanth N, Sun Y, Abramova N, Vincent P, Pumiglia K, Temple S: Endothelial cells stimulate self-renewal and expand neurogenesis of neural stem cells. Science 2004;304:1338-1340.

-90 Raab S, Beck H, Gaumann A, Yuce A, Gerber HP, Plate K, Hammes HP, Ferrara N, Breier $\mathrm{G}$ : Impaired brain angiogenesis and neuronal apoptosis induced by conditional homozygous inactivation of vascular endothelial growth factor. Thromb Haemost 2004;91: 595-605.

91 Martin P, Lewis J: Origins of the neurovascular bundle: interactions between developing nerves and blood vessels in embryonic chick skin. Int J Dev Biol 1989;33:379-387.

92 Mukouyama YS, Shin D, Britsch S, Taniguchi M, Anderson DJ: Sensory nerves determine the pattern of arterial differentiation and blood vessel branching in the skin. Cell 2002;109:693-705.

93 Mukouyama YS, Gerber HP, Ferrara N, Gu $C$, Anderson DJ: Peripheral nerve-derived VEGF promotes arterial differentiation via neuropilin-1-mediated positive feedback. Development 2005;132:941-952.

-94 Bates D, Taylor GI, Minichiello J, Farlie P, Cichowitz A, Watson N, Klagsbrun M, Mamluk R, Newgreen DF: Neurovascular congruence results from a shared patterning mechanism that utilizes semaphoring $3 \mathrm{a}$ and neuropilin-1. Dev Biol 2003;255:77-98.

$\$ 95$ Kutcher ME, Klagsbrun M, Mamluk R: VEGF is required for the maintenance of dorsal root ganglia blood vessels but not neurons during development. FASEB J 2004; 18: 1952-1954.

-96 Popovici C, Isnardon D, Birnbaum D, Roubin R: Caenorhabditis elegans receptors related to mammalian vascular endothelial growth factor receptors are expressed in neural cells. Neurosci Lett 2002;329:116-120.

97 Duchek P, Somogyi K, Jekely G, Beccari S, Rorth P: Guidance of cell migration by the Drosophila PDGF/VEGF receptor. Cell 2001;107:17-26.

-98 Heino TI, Karpanen T, Wahlstrom G, Pulkkinen M, Eriksson U, Alitalo K, Roos C: The Drosophila VEGF receptor homolog is expressed in hemocytes. Mech Dev 2001;109: 69-77.

-99 Cho NK, Keyes L, Johnson E, Heller J, Ryner L, Karim F, Krasnow MA: Developmental control of blood cell migration by the Drosophila VEGF pathway. Cell 2002;108:865876.

100 Sears HC, Kennedy CJ, Garrity PA: Macrophage-mediated corpse engulfment is required for normal Drosophila CNS morphogenesis. Development 2003;130:3557-3565.
01 Seipel K, Eberhardt M, Muller P, Pescia E, Yanze N, Schmid V: Homologs of vascular endothelial growth factor and receptor, VEGF and VEGFR, in the jellyfish, Podocoryne carnea. Dev Dyn 2004;231:303-312.

102 Hayashi T, Abe K, Suzuki H, Itoyama Y: Rapid induction of vascular endothelial growth factor gene expression after transient middle cerebral artery occlusion in rats. Stroke 1997;28:2039-2044.

103 Lennmyr F, Ata KA, Funa K, Olsson Y, Terent A: Expression of vascular endothelial growth factor and its receptors (Flt-1 and Flk1) following permanent and transient occlusion of the middle cerebral artery in the rat. J Neuropathol Exp Neurol 1998;57:874-882.

104 Plate KH, Beck H, Danner S, Allegrini PR, Wiessner C: Cell type specific upregulation of vascular endothelial growth factor in an MCA-occlusion model of cerebral infarct. $J$ Neuropathol Exp Neurol 1999;58:654-666.

105 Jin KL, Mao XO, Nagayama T, Goldsmith PC, Greenberg DA: Induction of vascular endothelial growth factor receptors and phosphatidylinositol 3'-kinase/Akt signaling by global cerebral ischemia in the rat. Neuroscience 2000;100:713-717.

106 Yang ZJ, Bao WL, Qiu MH, Zhang LM, Lu SD, Huang YL, Sun FY: Role of vascular endothelial growth factor in neuronal DNA damage and repair in rat brain following a transient cerebral ischemia. J Neurosci Res 2002;70:140-149.

107 Marti HJ, Bernaudin M, Bellail A, Schoch H, Euler M, Petit E, Risau W: Hypoxia-induced vascular endothelial growth factor expression precedes neovascularization after cerebral ischemia. Am J Pathol 2000;156:965-976.

108 Krum JM, Khaibullina A: Inhibition of endogenous VEGF impedes revascularization and astroglial proliferation: roles for VEGF in brain repair. Exp Neurol 2003;181:241257.

109 Cheng SY, Nagane M, Huang HS, Cavenee WK: Intracerebral tumor-associated hemorrhage caused by overexpression of the vascular endothelial growth factor isoforms VEGF121 and VEGF165 but not VEGF189. Proc Natl Acad Sci USA 1997;94:1208112087.

110 Van Bruggen N, Thibodeaux H, Palmer JT, Lee WP, Fu L, Cairns B, Tumas D, Gerlai R, Williams SP, van Lookeren Campagne $\mathrm{M}$, Ferrara N: VEGF antagonism reduces edema formation and tissue damage after ischemia/ reperfusion injury in the mouse brain. J Clin Invest 1999;104:1613-1620.

111 Zhang ZG, Zhang L, Jiang Q, Zhang R, Davies $\mathrm{K}$, Powers $\mathrm{C}$, Bruggen N, Chopp M: VEGF enhances angiogenesis and promotes blood-brain barrier leakage in the ischemic brain. J Clin Invest 2000;106:829-838.

112 Hayashi T, Abe K, Itoyama Y: Reduction of ischemic damage by application of vascular endothelial growth factor in rat brain after transient ischemia. J Cereb Blood Flow Metab 1998;18:887-895. 
113 Harrigan MR, Ennis SR, Sullivan SE, Keep RF: Effects of intraventricular infusion of vascular endothelial growth factor on cerebral blood flow, edema, and infarct volume. Acta Neurochir (Wien) 2003;145:49-53.

114 Harrigan MR, Ennis SR, Masada T, Keep RF: Intraventricular infusion of vascular endothelial growth factor promotes cerebral angiogenesis with minimal brain edema. Neurosurgery 2002;50:589-598.

-115 Sun Y, Jin K, Xie L, Childs J, Mao XO, Logvinova $A$, Greenberg DA: VEGF-induced neuroprotection, neurogenesis, and angiogenesis after focal cerebral ischemia. J Clin Invest 2003;111:1843-1851.

-116 Sun Y, Jin K, Childs JT, Xie L, Mao XO, Greenberg DA: Increased severity of cerebral ischemic injury in vascular endothelial growth factor-B-deficient mice. J Cereb Blood Flow Metab 2004;24:1146-1152.

- 117 Beck H, Acker T, Puschel AW, Fujisawa H, Carmeliet P, Plate KH: Cell type-specific expression of neuropilins in an MCA-occlusion model in mice suggests a potential role in post-ischemic brain remodeling. J Neuropathol Exp Neurol 2002;61:339-350.

-118 Schratzberger P, Walter DH, Rittig K, Bahlmann FH, Pola R, Curry C, Silver M, Krainin JG, Weinberg DH, Ropper AH, Isner JM: Reversal of experimental diabetic neuropathy by VEGF gene transfer. J Clin Invest 2001;107:1083-1092.

-119 Schratzberger P, Schratzberger G, Silver M, Curry C, Kearney M, Magner M, Alroy J, Adelman LS, Weinberg DH, Ropper AH, Isner JM: Favorable effect of VEGF gene transfer on ischemic peripheral neuropathy. Nat Med 2000;6:405-413.

-120 Wang Y, Kilic E, Kilic U, Weber B, Bassetti CL, Marti HH, Hermann DM: VEGF overexpression induces post-ischaemic neuroprotection, but facilitates haemodynamic steal phenomena. Brain 2005; 128:52-63.

121 Vaquero J, Zurita M, de Oya S, Coca S: Vascular endothelial growth/permeability factor in spinal cord injury. J Neurosurg Spine 1999; 90:220-223.

122 Skold M, Cullheim S, Hammarberg H, Piehl F, Suneson A, Lake S, Sjogren A, Walum E, Risling M: Induction of VEGF and VEGF receptors in the spinal cord after mechanical spinal injury and prostaglandin administration. Eur J Neurosci 2000;12:3675-3686.

-123 Hobson MI, Green CJ, Terenghi G: VEGF enhances intraneural angiogenesis and improves nerve regeneration after axotomy. $\mathrm{J}$ Anat 2000; 197:591-605.

- 124 Facchiano F, Fernandez E, Mancarella S, Maira G, Miscusi M, D'Arcangelo D, Cimino-Reale G, Falchetti ML, Capogrossi MC, Pallini R: Promotion of regeneration of corticospinal tract axons in rats with recombinant vascular endothelial growth factor alone and combined with adenovirus coding for this factor. J Neurosurg 2002;97:161-168.
125 Widenfalk J, Lipson A, Jubran M, Hofstetter C, Ebendal T, Cao Y, Olson L: Vascular endothelial growth factor improves functional outcome and decreases secondary degeneration in experimental spinal cord contusion injury. Neuroscience 2003;120:951-960.

126 Benton RL, Whittemore SR: VEGF165 therapy exacerbates secondary damage following spinal cord injury. Neurochem Res 2003;28: 1693-1703.

127 Rowland LP, Shneider NA: Amyotrophic lateral sclerosis. N Engl J Med 2001;344:16881700.

128 Cleveland DW, Rothstein JD: From Charcot to Lou Gehrig: deciphering selective motor neuron death in ALS. Nat Rev Neurosci 2001;2:806-819.

129 Murakami T, Ilieva H, Shiote M, Nagata T, Nagano I, Shoji M, Abe K: Hypoxic induction of vascular endothelial growth factor is selectively impaired in mice carrying the mutant SOD1 gene. Brain Res 2003;989:231-237.

130 Lambrechts D, Storkebaum E, Morimoto M, Del-Favero J, Desmet F, Marklund SL, Wyns S, Thijs V, Andersson J, van Marion I, AlChalabi A, Bornes S, Musson R, Hansen V, Beckman L, Adolfsson R, Pall HS, Prats H, Vermeire S, Rutgeerts P, Katayama S, Awata T, Leigh N, Lang-Lazdunski L, Dewerchin M, Shaw C, Moons L, Vlietinck R, Morrison KE, Robberecht W, Van Broeckhoven C, Collen D, Andersen PM, Carmeliet P: VEGF is a modifier of amyotrophic lateral sclerosis in mice and humans and protects motoneurons against ischemic death. Nat Genet 2003;34: 383-394.

131 Storkebaum E, Lambrechts D, Dewerchin M, Moreno-Murciano MP, Appelmans S, Oh H, Van Damme P, Rutten B, Man WY, De Mol M, Wyns S, Manka D, Vermeulen K, Van Den Bosch L, Mertens N, Schmitz C, Robberecht W, Conway EM, Collen D, Moons L, Carmeliet P: Treatment of motoneuron degeneration by intracerebroventricular delivery of VEGF in a rat model of ALS. Nat Neurosci 2005;8:85-92.

132 Azzouz M, Ralph GS, Storkebaum E, Walmsley LE, Mitrophanous KA, Kingsman SM, Carmeliet P, Mazarakis ND: VEGF delivery with retrogradely transported lentivector prolongs survival in a mouse ALS model. Nature 2004;429:413-417.

133 Sopher BL, Thomas PS Jr, LaFevre-Bernt MA, Holm IE, Wilke SA, Ware CB, Jin LW, Libby RT, Ellerby LM, La Spada AR: Androgen receptor YAC transgenic mice recapitulate SBMA motor neuronopathy and implicate VEGF164 in the motor neuron degeneration. Neuron 2004;41:687-699.

134 Perlmutter LS, Chui HC: Microangiopathy, the vascular basement membrane and Alzheimer's disease: a review. Brain Res Bull 1990;24:677-686.
135 Kalaria RN: Small vessel disease and Alzheimer's dementia: pathological considerations. Cerebrovasc Dis 2002;13(suppl 2):48-52.

136 Ho KL, Garcia JH: Neuropathology of the small blood vessels in selected diseases of the cerebral white matter; in Pantoni L, Inzitari D, Wallin A (eds): The Matter of White Matter. Dordrecht, ICG Publications, 2000, pp 247-273.

137 Kalaria RN, Kenny RA, Ballard CG, Perry R, Ince P, Polvikoski T: Towards defining the neuropathological substrates of vascular dementia. J Neurol Sci 2004;226:75-80.

138 Kalaria RN, Cohen DL, Premkumar DR, Nag S, LaManna JC, Lust WD: Vascular endothelial growth factor in Alzheimer's disease and experimental cerebral ischemia. Brain Res Mol Brain Res 1998;12;62:101-105.

139 Stopa EG, Berzin TM, Kim S, Song P, KuoLeBlanc V, Rodriguez-Wolf M, Baird A, Johanson CE: Human choroid plexus growth factors: What are the implications for CSF dynamics in Alzheimer's disease? Exp Neurol 2001;167:40-47.

140 Tarkowski E, Issa R, Sjogren M, Wallin A, Blennow K, Tarkowski A, Kumar P: Increased intrathecal levels of the angiogenic factors VEGF and TGF- $\beta$ in Alzheimer's disease and vascular dementia. Neurobiol Aging 2002;23:237-243.

141 Colangelo V, Schurr J, Ball MJ, Pelaez RP, Bazan NG, Lukiw WJ: Gene expression profiling of 12633 genes in Alzheimer hippocampal CA1: transcription and neurotrophic factor down-regulation and up-regulation of apoptotic and pro-inflammatory signaling. J Neurosci Res 2002;70:462-473.

142 Pogue AI, Lukiw WJ: Angiogenic signaling in Alzheimer's disease. Neuroreport 2004; 15: 1507-1510.

143 Yang SP, Bae DG, Kang HJ, Gwag BJ, Gho YS, Chae CB: Co-accumulation of vascular endothelial growth factor with $\beta$-amyloid in the brain of patients with Alzheimer's disease. Neurobiol Aging 2004;25:283-290.

144 Yasuhara T, Shingo T, Kobayashi K, Takeuchi A, Yano A, Muraoka K, Matsui T, Miyoshi Y, Hamada H, Date I: Neuroprotective effects of vascular endothelial growth factor upon dopaminergic neurons in a rat model of Parkinson's disease. Eur J Neurosci 2004; 19: 1494-1504.

145 Feiner L, Webber AL, Brown CB, Lu MM, Jia L, Feinstein P, Mombaerts P, Epstein JA, Raper JA: Targeted disruption of semaphorin $3 \mathrm{C}$ leads to persistent truncus arteriosus and aortic arch interruption. Development 2001; 128:3061-3070.

146 Toyofuku T, Zhang H, Kumanogoh A, Takegahara N, Suto F, Kamei J, Aoki K, Yabuki M, Hori M, Fujisawa H, Kikutani H: Dual roles of Sema6D in cardiac morphogenesis through region-specific association of its receptor, plexin-A1, with off-track and vascular endothelial growth factor receptor type 2 . Genes Dev 2004; 18:435-447. 